\section{Attitudes and Habits of Young Adults in Using The Services of Fast Food Restaurants}

\author{
Dunja Demirović - Bajrami, Karolina Simat, \\ Nikola D. Vuksanović, Marija Cimbaljević
}

JEL Classification: L15, L21, M31

\section{INTRODUCTION}

Some authors defined fast food as packed, quickly prepared, suitable meals, while on the other side there is a a simpler definition which described fast food as food bought in some fast food restaurants such as McDonald's (Dunn, Mohr, Wilson \& Wittert, 2011). Fast food is marked by low prices, large portions and by food that has a lot of calories and fats (Bowman \& Vinyard, 2004; Guthrie, Lin \& Frizao, 2002; Brindal, Mohr, Wilson \& Wittert, 2008; Namin, 2017). Individuals and whole families eat fast food for several reasons: because of the time and budget, because it is not expensive, it is quick to prepare, it is tasty and available (Rydell, 2008; Laxer \& Janssen, 2014).

The strengthening of knowledge in society, increase interest in environmental issues and economic development had significant impact on shaping consumer demands and consequently consumption patterns. Therefore, implementing and following certain ethical principles have become an indispensable part of the organization' strategy for keeping position on the market and gaining new consumers. Information about which ethical principles some organization follows can have infulence on the level of the product sales and how customers perceive the image of that organization (Mohr, Webb \& Harris, 2001). Schröder and McEachern (2005) emphasized that corporate image can be created as a mix of tangible (for example, products) and intangible attributes (such as CSR initiatives). Evenly significant is the way in which organizations interact with their stakeholders through different strategies, including corporate social responsibility initiatives. Van den Bogaerd and Aerts (2015) revealed that organization that has a favorable reputation in media can also savor a favorable credit quality both from their customers and suppliers.

Global social trends, which the Serbian traditional culture tends to follow, have influenced the creation of new eating habits. Research on the consumption of fast food and academic approach to the topic of fast food restaurants in Serbia are still scarce, so based on the all reasons mentioned above, young consumers from 17 to 25 years of age were selected as the target group. They have already formed some eating habits, but also dispose with money and freedom of food choice on daily basis. The aim
Abstract: The purpose of the paper was to investigate the attitudes and perceptions of young people about the fast food restaurants in Serbia, with the special emphasis to the elements of corporate social responsibility (brand, nutritional values, ethical values and the quality of food), and to show the extent to which these products are represented in their daily diet. Data were collected from February to June 2019 between students of the University of Belgrade and Novi Sad, and between young people at high schools in Belgrade and Novi Sad (Serbia). A total sample consisted of 1145 young consumers. It was evident that the values and preferences of the target group of the leading fast food restaurants have changed, in the already developed market as well as in the developing ones, such as Serbia. The paper presents empirical results of using the services of fast food restaurants in Serbia by the younger population, as well as their perception of corporate social responsibility, with the special emphasis to the restaurants of McDonald's and KFC.

Key words: corporate social responsibility, young consumers, attitudes and perceptions, eating habits, fast food, restaurants, Serbia 
of this study is to analyze the attitudes and perceptions of young people regarding the fast food restaurants in Serbia, with the special emphasis to the brand, nutritional value, quality and ethical values and effects of communicating CSR initiatives to young consumers.

\section{LITERATURE REVIEW}

Worldwide fast food markets and changing competitive environment has pointed out in greater attention focused on the market and its contribution to the notions of the common good. Đokić (2017) pointed out that consumer decision-making, an individual's assessment or awareness of environmental values can interested subject attitudes and behaviors as well as influence their attitudes toward consumption in restaurants. In that sense, Vapa-Tankosić and Hanić (2019) suggest using environmental exploring to distinguish products from other brands. Kasim \& Ismail (2012) suggest to management if they want to build a good image, strengthen relations with customers, and promote more harmonious relations within society to follow environmentally responsible practices.

All relevant initiatives fast food leader tend to promote through modern marketing channels. For example, McDonald's highlighted on their web sites that the company is "doing the right thing for the local communities", by giving different support to local schools and sport clubs. Also, this company has various promotional activities through which it emphasizes the importance of preserving the environment by recycling, using biodegradable packaging or creating spaces which will emit less carbon monoxide (Grankvist, Dahlstrand \& Biel, 2004).

However, studies regarding the global CSR initiatives were mostly done in western countires, and those results sometimes may not be applicable on other countires, especially developing ones (Takano, 2013). Having this in mind, it would be significant to analyze effects of communicating CSR initiatives to young consumers in transitional countries and emerging food markets.

Previous studies showed that eating habits were usually acquired in childhood, in the circle of family and friends, and thus affected the frequency of consumption of fast food at an old age (Davy, Benes \& Driskell, 2006). Many students, when they started studying, left their home, i.e., they did not live with their parents any more, which affected the change in their eating habits (El Ansari, Stock \& Mikolajczyk, 2012; Alviola IV, Nayga, Thomsen, Danforth \&
Smartt, 2014). They often chose less healthy food that could be quickly and easily prepared (Rubina et al., 2009), so they were classified as a risk group for eating unhealthy food. The consumption of food at fast food restaurants became a part of the lifestyle of young people (Davy et al., 2006; Seo, Lee, \& Nam, 2011). It was believed that the poor eating habits of young people were the consequence of a greater exposure to stress and lack of time during their studies (Rubina et al., 2009; El Ansari et al., 2012) and that these habits should have been temporary. However, research showed that people preserved these habits later in life (Silliman, Rodas-Fortier \& Neyman, 2004). Poor eating habits among young people were associated with skipping meals, eating food outside the home, using most often a variety of snacks and fast food (Savige, Ball \& Worsley, 2007; Seo et al., 2011; El Ansari et al., 2012).

Among the most important factors that contributed to the rising demand for fast food was the growing number of shopping centers, vending machines and fast-food restaurants (King, Mohl, Bernard \& Vidourek, 2007; Ohri-Vachaspati et al., 2015), as well as their better promotion on television and the Internet. The researchs (Davis \& Carpenter, 2009; Forsyth, Wall, Larson, Story \& Neumark-Sztainer, 2012; Laxer \& Janssen, 2014) showed that young people whose educational institutions were located close to the fast food restaurants were more obese compared to students in whose vicinity there were no fast food restaurants.

The greatest number of studies about the fast food consumption was conducted in USA (Davy et al., 2006; Hertzler \& Frary, 1996; Driskell, Meckna \& Scales, 2006; Forsyth et al., 2012; Ohri-Vachaspati et al., 2015). The research conducted among Americans (Morse \& Driskell, 2009) showed that young people bought fast food once to three times a week and that they ordered the food that looked good or the food that they thought was healthier. A rising number of studies about the consumption of fast food in developing countries were noticeable, as well. The research of El Ansari et al. (2012) showed that there were various patterns of consuming fast food among young people. Research conducted in Pakistan (Yahya, Zafar \& Shafiq, 2013) showed that respondents believed that eating fast food did not save them money and that fast food was mostly used for pleasure and fun. Also, young people believed that the frequent consumption of fast food could lead to health problems and obesity, and that it very easy created a sense of addiction among people of all ages. Attitudes of young adults towards the consequences of consumption of fast food 
for their health are not consistent. Fisher, Erasmus and Viljoen (2016) showed that young adults were not concern about the impact of fast food on their health, while Mattsson and Helmersson (2007) indicated that high-school students in Sweden were aware of positive and negative characteristics of fast food consumption, especially that fast food consumption creates addiction and can have negative side effects on health. All authors agreed that it is necessary to raise awareness of the consequences of frequent consumption of fast food on future health of young adults not only because of themselves but because, one day, they will be decision makers for buying groceries in their households.

The first large chain of fast food restaurants, $M c$ Donald's restaurant in Serbia and Southeast Europe was opened in 1988 in Belgrade. One of the postulates of McDonald's restaurants, that is applied as well in Serbia, is a concern for the environment in which it is located (Šćepanović, 2002). In 2018, McDonald's had 26 restaurants - 16 in Belgrade, 3 in Novi Sad and 7 restaurants in smaller cities (Subotica, Pančevo, Velika Plana, Kragujevac, Niš and Stara Pazova), where restaurants were mostly located on the highway next to these cities (https://www.mcdonalds.rs/restorani/). Unlike McDonald's, KFC (Kentucky Fried Chicken) restaurants have a much shorter history in Serbia. The first restaurant was opened in 2007 and in 2018 there were seven restaurants in Belgrade and one in Novi Sad (https://www.kfc.rs/restorani/). Quality and presentation of the food, variety of items on the menu, cleanliness of the restaurant and location were the most significant factors when choosing fast food restaurants among students in Serbia (Blešić, Raljić, Pivac, Ivkov, 2018). Foreign fast food restaurants can rarely satisfy costumer's desire for uniqueness since they have standardized products, but there were more interesting compared to domestic fast food restaurants since they provided different and novel experience (Sapic, Filipovic, Dlacic, 2019).

Previous studies about the consumption of fast food have shown the influence of socio-demographic characteristics on the consumption of fast food (Anderson, Rafferty, Lyon-Gallo \& Fussman, 2011; Tomić, Fočić, Marijanović \& Topličanec, 2012; Ayo, Bonabana-Wabbi \& Sserunkuuma, 2012; El Ansari et al., 2012). The aim of this paper is, among other things, to determine whether this trend is typical for young people in Serbia as well.

\section{METHODOLOGY}

\subsection{Questionnaire}

The questionnaire used in the study was created based on the literature related to the same subject in gastronomy and ethics, analyzing shopping habits and motives for the consumption of fast food among young people (Schröder \& McEachern, 2005). The scale used in this research was already validated. Previous studies indicated that younger people were more prone to the consumption of fast food (Paeratakul, Ferdinand, Champagne, Ryan \& Bray, 2003; Driskell et al., 2005; Akbay, Gulgun \& Gul, 2007; Anderson, et al., 2011; El Ansari et al., 2012; Laxer \& Janssen, 2014) and that the target group of the consumers of world's leading fast food restaurant chains were young people aged between 17 and 25 years. Based on that, for the purposes of this study, the research was conducted between this age group. The questionnaire had three parts. The first had five demographic questions related to the gender, age, education, income, and with whom respondents currently lived. The second included questions related to the frequency and habits in the consumption of fast food (portion size, reasons for purchase). The third part consisted of the statements related to the perceived values of corporate social responsibility expressed through the 19 attributes. The respondents expressed their opinion on a five-point Likert scale - 1 (strongly disagree) to 5 (strongly agree).

Two research questions arised from the aim of the research: Are young adults aware of the consequences of fast food consumption for their health? Is it expected from fast food restaurants to, through its products and services, take care of consumers' health, brand and ethical values?

\subsection{Sample}

The data were collected from February to June 2019 between students of the University of Belgrade and Novi Sad (total sample of 580 students), and between young people at high schools in Belgrade and Novi Sad (total sample of 565 pupils). Researchers have chosen young adults from Belgrade and Novi Sad since these two cities had the largest number of fast food restaurants, and the largest universities as well as a higher number of high schools were located in these cities in Serbia. An email which contained the link to the survey was sent to students of the University of Novi Sad and Belgrade by the University's Registrar Offices, while in high schools, with the approval of the school board, the researchers personally interviewed 
third and fourth graders during their classes. Out of the 1300 distributed questionnaires, 1150 were returned, and after reviewing them, only those which were properly filled in were kept. From the total number, five questionnaires were improperly filled, which left the total sample of 1145 questionnaires for analysis.

Table 1 presents the results of descriptive analysis of the demographic information of the respondents (young people). It is notable that numerous consumers of fast food were females (58\%) and people aged between 17 to 19 (40.8\%) who were finishing their high schools. More than half of the respondents did not live with their parents (dorm $28.1 \%$ and rented apartment $35.2 \%$ ) with total personal monthly family income between 401 and 600 euros (36\%) and 201 and 400 euros (29.8\%).

TABLE 1. Demographic information for the respondents

\begin{tabular}{|c|c|c|}
\hline Variables & & $\begin{array}{c}\text { Percentage } \\
\text { (\%) }\end{array}$ \\
\hline Gender & $\begin{array}{l}\text { Male } \\
\text { Female }\end{array}$ & $\begin{array}{l}42.0 \\
58.0\end{array}$ \\
\hline Age & $\begin{array}{l}17-19 \\
20-22 \\
23-25\end{array}$ & $\begin{array}{l}40.8 \\
33.6 \\
25.6\end{array}$ \\
\hline $\begin{array}{l}\text { Level of } \\
\text { studies }\end{array}$ & $\begin{array}{l}\text { High school } \\
\text { Faculty }\end{array}$ & $\begin{array}{l}50.7 \\
49.3\end{array}$ \\
\hline Total & Less than 200 & 21.5 \\
\hline monthly & $201-400$ & 29.8 \\
\hline family & $401-600$ & 36.0 \\
\hline income (€) & over 600 & 12.7 \\
\hline \multirow{3}{*}{$\begin{array}{l}\text { I currently } \\
\text { live }\end{array}$} & In family home & 36.7 \\
\hline & In the dorm & 28.1 \\
\hline & In the rented apartment & 35.2 \\
\hline
\end{tabular}

SouRcE: Authors, based on statistical analysis of survey data

\subsection{Statistical data processing}

In order to examine the attitudes of young people in terms of fast-food restaurants and their business, several types of statistical analysis were conducted. Oneway analysis of variance of the data (frequency and distribution) was performed first, in order to identify the main socio-demographic indicators and reasons for consuming fast food. Also, authors conducted a statistical technique for determining the connections and differences between groups: T-test of paired samples, one-way analysis of variance (ANOVA) and chisquare test of independence, in order to determine whether there were differences according to certain criteria (gender, age, reasons for consuming fast food, etc.), and at the end the factor analysis with the aim of selecting the most important factors. Statistical Package for Social Sciences (SPSS version 21) was used to execute the specified statistical analysis.

Factor 1 included the views of respondents referring to the elements of communication of the fast food restaurants' brand with the target group. Factor 2 included the views of respondents regarding the health aspect of consuming fast food and it was called the „nutritional values“. Factor 3 consisted of attitudes regarding the ethics of the production and consumption of fast food, and it was called "the ethical values", while factor 4 encompassed attitudes about the quality of food.

\section{RESULTS AND DISCUSSION}

Analysis of the frequency of consumption of fast food among Serbian young people showed that the largest number of students visited McDonald's ,several times a year" $(40.3 \%)$ or did not visit it at all (39.4\%). The highest percentage of the young people (78.8\%) never used services of the fast food restaurants KFC, while the other fast food restaurants such as pizza places, hamburger places were more popular among Serbian young people, and they visited them at least once a month $(36.4 \%)$, several times per week $(18.2 \%)$ or weekly (19\%). Overall, this trend of the consumption of fast food was present in the other countries as well - America (Morse \& Driskell, 2009), Croatia (Tomić et al., 2012), Korea (Kim, Shin \& Moon, 2004) and in research of El Ansari et al., (2012).

One-way analysis of variance studied the effect of the living conditions (in the family, in the dorms and private apartment), on the frequency of use of services of fast food restaurants. Although previous research suggested that people who lived in the households with a greater number of members ( $>4$ members) and in the households with higher incomes, more frequently ate fast food (Stewart \& Yen, 2004; Akbay et al., 2007; Ayo et al., 2012), research in Serbia showed that there was no statistically significant difference in the results obtained with the three groups of living conditions $(\mathrm{F}(2,228)=2.46, \mathrm{p}=0.08)$. The real difference between the mean values of the groups was very small. Also, there was no difference between the frequency of the consumption of fast food with respect to the other socio-demographic characteristics (gender and level of personal monthly income). These results coincided with the results of research conducted 
TABLE 2. Oblimin rotation for 19 items from the scale $(\mathrm{N}=1145)$

\begin{tabular}{|c|c|c|c|c|}
\hline \multirow{2}{*}{ Attitudes } & \multicolumn{4}{|c|}{ Factor } \\
\hline & 1 & 2 & 3 & 4 \\
\hline \multicolumn{5}{|l|}{ Brand value } \\
\hline Fast food companies should have a larger organic range. & .214 & -.086 & -.057 & -.591 \\
\hline Leaflets describing fat content of meals should be available in all fast-food outlets. & .170 & & .064 & -.663 \\
\hline Fast food companies offer good value for money. & -.033 & -.440 & -.136 & \\
\hline Fast food companies must communicate more with the general public. & & .560 & & -.437 \\
\hline I prefer to read food information to getting it from the TV. & .456 & -.064 & .243 & -.480 \\
\hline $\begin{array}{l}\text { I am interested to see behind the scenes (e.g. kitchens, equipment) in fast-food } \\
\text { restaurants. }\end{array}$ & .078 & .109 & -.039 & -.578 \\
\hline \multicolumn{5}{|l|}{ Nutritional value } \\
\hline KFC products are unhealthy. & .892 & & -.120 & -.095 \\
\hline McDonalds products are unhealthy. & .891 & -.130 & -.089 & -.079 \\
\hline Fast food companies encourage you to eat more than you need. & .477 & .074 & -.097 & -.415 \\
\hline Only quality ingredients are used to manufacture fast-food products. & .550 & -.427 & -.176 & -.392 \\
\hline \multicolumn{5}{|l|}{ Ethical value } \\
\hline It is acceptable to keep chickens in a battery cage. & -.311 & & .385 & \\
\hline McDonalds cannot be blamed for rising rates of obesity in Serbia. & -.059 & .188 & .927 & -.079 \\
\hline KFC cannot be blamed for rising rates of obesity in Serbia. & -.042 & .197 & .928 & \\
\hline Animal welfare refers mainly to chicken production. & -.064 & .621 & .189 & .098 \\
\hline \multicolumn{5}{|l|}{ Food quality } \\
\hline Fast food products should have a GM free label. & & .140 & .199 & -.581 \\
\hline I always try to buy meat that originates from Serbia. & .128 & .321 & .052 & -.354 \\
\hline I now visit fast-food outlets more as a result of their healthy eating promotions. & -.269 & .486 & .031 & .129 \\
\hline Animal welfare assurances are a good indicator of meat quality. & & .542 & .052 & -.252 \\
\hline Cheap meat results in worse conditions for animals. & .064 & .673 & & -.090 \\
\hline
\end{tabular}

SOURCE: Authors, based on statistical analysis of survey data

in the region, namely in the former Yugoslav Republic - Croatia (Tomić et al. 2012).

As far as the size of the portions was concerned, young people usually bought a "standard“ size portion (51.1\%). Chi-square test indicated a meaningful connection among the gender and the size of servings $(\mathrm{X} 2(3)=32.150, \mathrm{p}<0.005)$. From the total sample of female respondents, $56.7 \%$ ordered standard size portions, while within the total sample of male respondents, $43.3 \%$ of them ordered standard size portions. When it comes to the fact whether the young people lived with their families, in the dormitory or in a private apartment, the results pointed out that this criterion had a small impact on the choice of portion sizes $\left(\mathrm{X}^{2}(6)=5.040 ; \mathrm{p}=0.539 ; \mathrm{V}=0.104\right)$. Young people who lived in private apartments mostly ordered standard (37.1\%) and large portions (40\%), while those who lived with their parents ordered mostly small portions of fast food (51.1\%).
The most important thing for young people, when they should express a particular concern about healthy fast food, was the quantity of the portions (66.8\%), while the number of calories (17.6\%), amount of sugar (10.9) and fat content (4.7\%) were much less represented. Chi-square test revealed a weak connection among the gender and care about healthy food $\left(\mathrm{X}^{2}(4)\right.$ $=7.151 ; \mathrm{p}=0.128 ; \mathrm{V}=0.176)$. Quantity of portions when consuming fast food was a matter of concern for an equal number of both gender group.

Reasons why young people consumed fast food was measured using a scale of 5 degrees, where 1 denoted the lowest and 5 the highest mark. The most important reasons were "availability" (mean value 3.81), „taste“ (mean value 3.57) and ,inexpensive way to eat out somewhere" i.e. "price" of fast food (mean value 3.57). These were the basic characteristics of fast food, and similar results were obtained in studies of 
Driskell et al. (2005), Schröder and McEachern (2005) and Tomić et al. (2012).

Attitudes and perceptions of young people about the corporate social responsibility of fast food restaurants in Serbia through the 19 items were subjected to principal component analysis (PCA). Before the implementation of the PCA, the convenience of data for factor analysis was evaluated. The value of the KaiserMeyer indicator was 0.73, while the Bartlett's test of sphericity had a statistical significance on the level of $\mathrm{p}=0.000$, which pointed to the factorability correlation matrix.

The seven components had characteristic values above 1 , which explained the cumulative variance of $63.76 \%$. By examining the diagram of the pass, the existence of a clear point of fracture after fourth component was established. Based on the recommendations of Catell (1966) it was chosen to retain those four components for further exploration. The contribution of the first and the second components was $30.2 \%$, first three components $39.1 \%$, while the four component solution explained $46.9 \%$ of variance. For the easier interpretation of the four components, oblimin rotation was conducted. Rotated solution revealed the existence of a simple structure in which all the components had bigger factor weights and all variables provided significant weight just after one of the components. Interpretation of the obtained components was not entirely in accordance with the previous research of the applied scale, i.e. the results partially supported the usage of items in the form of separate scales, as suggested by the authors of the scale (Schröder \& McEachern, 2005).

Results obtained by the conducted research in Serbia suggested the modification of the structure of components, whereby their essence remained unchanged. Items gave great weights of components, and between all the four factors there was a weak correlation, being positive only between components 2 and 3 , and negative in between all the others, as shown in the Table 3.

The results of an exploratory factor analysis revealed that the target group had some positive, but also negative viewpoint of fast food restaurants and some aspects of their corporate social responsibility. When it comes to the fast food brand value, $73.2 \%$ of the target group believed that fast food restaurants should have a larger selection of organic foods, which, according to $77.9 \%$ of respondents, should have a label that it was not a genetically modified product. 48.5 of respondents believed that fast food restaurants had to communicate more with the public, while $77.5 \%$
TABLE 3. Correlation between the obtained factors

\begin{tabular}{|c|c|c|c|c|}
\hline \multicolumn{5}{|c|}{ Component Correlation Matrix } \\
\hline Component & $\mathbf{1}$ & $\mathbf{2}$ & $\mathbf{3}$ & $\mathbf{4}$ \\
\hline 1 & 1.000 & -.080 & -.111 & -.238 \\
\hline 2 & -.080 & 1.000 & .109 & -.082 \\
\hline 3 & -.111 & .109 & 1.000 & -.042 \\
\hline 4 & -.238 & -.082 & -.042 & 1.000 \\
\hline
\end{tabular}

Extraction Method: Principal Component Analysis. Rotation Method: Oblimin with Kaiser Normalization.

SouRCE: Authors, based on statistical analysis of survey data

agreed with the statement that the fliers that will give details about the fat content should be available in all the restaurants of this type. About the importance of business transparency and preparation of fast food for consumers testifies the fact that $80.1 \%$ of young people would like to see how the food service facility functions beyond the sales counter, in the kitchen for example.

When it comes to the nutritional value of the food distributed by the world's leading fast food restaurants, a great part of respondents believed that these products were unhealthy, namely $64.5 \%$ of young people believed that the products of $K F C$ restaurants were unhealthy and $67.9 \%$ that the fast food offered by McDonald's was also unhealthy. Moreover, almost the same number of students believed that fast food restaurants made them eat more than they really needed (68.9\%) and did not believe that the quality ingredients were used in its production (69.8\%). Regarding the ethical values of the production and consumption of fast food, one-quarter of young people believed that KFC (28.2\%) and McDonald's (26.5\%) could be accused for the increased rate of obesity of the population of Serbia. Approximately the same proportion of respondents disagreed with this statement (36.4\%) and was not sure (33.8\%) whether it was okay to raise poultry in separate cages. Trend of breeding poultry in these conditions was a relatively new phenomenon in Serbia and it was obvious that a large number of the younger population was not familiar with it. In this sense, in terms of the quality of fast food, more than half of the respondents were not sure whether the poultry production was done in better conditions than in the rearing of other animals (52.8\%), but they believed that guaranteed animal well-being was a good indicator of the quality of meat (55.8\%) and that cheap meat was a result of the poor conditions in which animals were raised (52.4\%). Also, in terms of the quality, most reported that they tended to buy 
meat that originated from Serbia (63.2\%). Although a majority of young people believed that fast food was not characterized by high-quality foods, or $73.2 \%$ did not visit a fast food restaurant for the promotion of healthy eating, the target group remained relatively neutral in the terms of the price and quality ratio. Specifically, an equal part of respondents expressed both positive and negative attitude about this ratio $(28.2 \%)$, while the remaining $43.7 \%$ said they were not sure whether fast food offered good value for money.

As in the majority of developing countries there was also a trend of consuming food outside the home in the urban areas of Serbia, especially among the younger population. Although in the territory of Serbia, fast food restaurants have a tradition which is three decades long, the international chain of fast food did not expand at the same speed and in the same extent as it was the case in the other parts of Europe. Moreover, in Serbia there have been evident cases of closure of McDonald's restaurants in the last decade, in the towns of Zrenjanin, Čačak, Kragujevac and Jagodina. In the other fast-food restaurants (hamburger places, pizza places) young people ate at least once a month $(36.4 \%)$, once a week $(18.2 \%)$ or several times a week (19\%). The reason for that was, above all, the fact that Southeast Europe had a tradition of fast food and already well-established domestic products such as bakery products, burek, pizzas, kebabs, etc. In addition, the present circumstances in Novi Sad were confirmed by the existing research on the importance of location in consumers' preferences in the selection of fast-food restaurants. Namely, the restaurants McDonald's and KFC in Serbia are often located in the city centre or in large department stores farther from the centre. Specifically, in Novi Sad, the only KFC restaurant is located in a department store $5 \mathrm{~km}$ far from the city centre and $6.5 \mathrm{~km}$ far from the students' centre, unlike McDonald's restaurant which is located right in the city centre. In this sense, it was evident that the target group in this study visited $M c^{-}$ Donald's restaurants more frequently. It is also necessary to note that in Novi Sad and Belgrade there are 3 restaurants of the food for students which offer complete meals at very low prices. Two restaurants are located in the Students' Center, close to the most of the faculties and student dormitories and one in the very centre. Having this in mind, it is understandable why a greater part of the target group in Novi Sad, had no need to consume fast food every day or even to visit fast-food restaurants.

\section{CONCLUSION}

The contributions of the study are twofold. It contributes academic approach to the topic of fast food consumption by young people in Serbia and indicate that domestic fast food products are much more represented in their daily diet then the products of world's leading fast food chains. Furthermore, the results could help managers of fast food companies to assess their market strategies not only for the Serbia market but also for the market in the region. It is evident that the values and preferences of the target group of the leading fast food restaurants have changed, in the already developed market as well as in the developing ones, such as Serbia. It is clear that big companies are no longer allowed to rely only on convenience and consistency of the product, but it is necessary to take into account very complex values such as consumers' health, product quality and socially responsible initiatives. If the world's fast food brands such as McDonald's and KFC restaurants want to keep a dominant leading position in the market and attract new consumers in the developing markets, their overall brand has to follow the increasingly complex needs and preferences of consumers.

This paper presents the empirical results of using the services of fast food restaurants in Serbia by the younger population, as well as their perception of corporate social responsibility, with the special emphasis to the restaurants of McDonald's and KFC. However, there were some limitations. Clearly, because the focus of the research was on one country, its conclusions may be confined to Serbia. Due to the fact that the study included only young people aged 17 to 25 years in the area of Novi Sad and Belgrade, generalization of the results should be interpreted with caution. A larger sample might provide more detailed results in the field of fast food consumption.

The suggestions for future research were mainly connected with the limitations of the research. Future research should expand to the sample of people of other age groups, especially young people in primary and secondary schools and families from different parts of the country, in order to secure a complex picture of the habits and attitudes of the fast food consumption in Serbia. Also, the future research should include specific types of fast food and encompass other brands (eg. Caribic Pizza). Systematic approach to the academic study of the fast food market in Serbia will provide important information for professionals in the marketing of food, as well as for the entire food industry. 


\section{Acknowledgement:}

This research has been supported by the Ministry of Education, Science and Technological Development, Serbia (project III47007).

\section{References}

1. Akbay, C.T., Gulgun, Y., \& Gul, A. (2007). Consumer Characteristics Influencing Fast Food Consumption in Turkey. Food Control, 18(8).

2. Alviola IV, P. A., Nayga Jr, R. M., Thomsen, M. R., Danforth, D., \& Smartt, J. (2014). The effect of fastfood restaurants on childhood obesity: a school level analysis. Economics \& Human Biology, 12, 110-119.

3. Anderson, B., Rafferty, A., Lyon-Callo, S., Fussman, C., \& Gwendoline, I. (2011). Fast-Food Consumption and Obesity Among Michigan Adults. Preventing Chronic Disease, 8(4), A71.

4. Ayo, S., Bonabana-Wabbi, J., \& Sserunkuuma, D. (2012). Determinants of Fast Food Consumption in Kampala, Uganda. African Journal of Food, Agriculture, Nutrition and Development, 12(5), 6567 6581.

5. Blešić, I., Raljić, J.P., Pivac, T., Ivkov, M. (2018). Factors Influencing Students' Choice of Fast Food Restaurants. Economics of Agriculture / EkonomikaPoljoprivrede, 65(1), 257-268. https://doi. org/10.5937/ekoPolj1801257B

6. Bowman, S.A., \& Vinyard, B.T. (2004). Fast Food Consumption of U.S. Adults: Impact on Energy and Nutrient Intakes and Overweight Status. Journal of the American College of Nutrition, 23(2), 163-168.

7. Brindal, E., Mohr, P., Wilson, C., \& Wittert, G. (2008). Obesity and the Effects of Choice at a Fast Food Restaurant. Obesity Research \& Clinical Practice, 2(2), 111-117. doi: 10.1016/j.orcp.2008.03.004

8. Catell, R.B. (1966). The Screen Test for Number of Factors. Multivariate Behavioral research, 1(2), 245276.

9. Davis, B., \& Carpenter, C. (2009). Proximity of FastFood Restaurants to Schools and Adolescent Obesity. American Journal of Public Health, 99(3), 505-510.

10. Davy, S.R., Benes, B.A., \& Driskell, J.A. (2006). Sex Differences in Dieting Trends, Eating Habits, and Nutrition Beliefs of a Group of Midwestern College Students. Journal of the American Dietetic Association, 106(10), 1673-1677.

11. Driskell, J.A., Kim, Y., \& Goebel, K.J. (2005). Few Differences Found in the Typical Eating and Physical Activity Habits of Lower-level and Upper-level University Students. Journal of the American Dietetic Association, 105(5), 798-801.

12. Driskell, J.A., Meckna, B.R., \& Scales, N.E. (2006). Differences Exist in the Eating Habits of University
Men and Women at Fast-food Restaurants. Nutrition Research, 26(10), 524-530.

13. Dunn, K., Mohr, P., Wilson, C., \& Wittert, G.A. (2011). Determinants of fast-food consumption. An application of the Theory of Planned Behaviour. Appetite, 57(2), 349-357.

14. Đokić, I. (2017). Percipirani uticaj medija na ponašanje potrošača prehrambenih proizvoda. Marketing, 48(1), 20-29.

15. El Ansari, W., Stock, C., \& Mikolajczyk, R. T. (2012). Relationships between food consumption and living arrangements among university students in four European countries-a cross-sectional study. Nutrition journal, 11(1), 28.

16. Fisher, H., Erasmus, A. C., \& Viljoen, A. T. (2016). Young adults' consideration of their food choices a propos consequences for their future health. International Journal of Consumer Studies, 40(4), 475-483. https://doi.org/10.1111/ijcs.12273

17. Forsyth, A., Wall, M., Larson, N., Story, M., \& Neumark-Sztainer, D. (2012). Do adolescents who live or go to school near fast-food restaurants eat more frequently from fast-food restaurants?. Health \& place, 18(6), 1261-1269.

18. Grankvist, G., Dahlstrand, U., \& Biel, A. (2004). The impact of environmental labelling on consumer preference: negative vs positive labels. Journal of Consumer Policy, 27(1), 213-30.

19. Guthrie, J.F., Lin. B.H., \& Frazao, E. (2002). Role of Food Prepared Away from Home in the American Diet, 1977-78 versus 1994-96: Changes and Consequences. Journal of Nutrition Education and Behavior, 34(3), 140-150.

20. Hertzler, A.A., \& Frary, R.B. (1996). Family Factors and Fat Consumption of College Students. Journal of the American Dietetic Association, 95(9), A62.

21. Kasim, A., \& Ismail, A. (2012). Environmentally friendly practices among restaurants: drivers and barriers to change. Journal of Sustainable Tourism, 20(4), 551-570.

22. Kim, K.W., Shin, E.M., \& Moon, E.H. (2004). A Study on Fast Food Consumption, Nutritional Knowledge, Food Behavior and Dietary Intake of University Students. Journal of the Korean Dietetic Association, 10(1), 13-24.

23. King, K.A., Mohl, K., Bernard, A.L., \& Vidourek, R.A. (2007). Does Involvement in Healthy Eating Among University Students Differ Based on Exercise Status 
and Reasons for Exercise?. Californian Journal of Health Promotion, 5(3), 106-119.

24. Laxer, R. E., \& Janssen, I. (2014). The proportion of excessive fast-food consumption attributable to the neighbourhood food environment among youth living within $1 \mathrm{~km}$ of their school. Applied Physiology, Nutrition, and Metabolism, 39(4), 480-486.

25. Mattsson, J., \& Helmersson, H. (2007). Eating fast food: attitudes of high-school students. International Journal of Consumer Studies, 31(1), 117-121. https:// doi.org/10.1111/j.1470-6431.2006.00576.x

26. Mohr, L.A., Webb, D.J., \& Harris, K.E. (2001). Do consumers expect companies to be socially responsible? The impact of corporate social responsibility on buying behaviour. Journal of Consumer Affairs, 35(1), 45-73.

27. Morse, K.L., \& Driskell, J.A. (2009). Observed Sex Differences in Fast-food Consumption and Nutrition Self-assessments and Beliefs of College Students. Nutrition Research, 29(3), 173-179.

28. Namin, A. (2017). Revisiting customers' perception of service quality in fast food restaurants. Journal of Retailing and Consumer Services, 34, 70-81.

29. Ohri-Vachaspati, P., Isgor, Z., Rimkus, L., Powell, L. M., Barker, D. C., \& Chaloupka, F. J. (2015). Childdirected marketing inside and on the exterior of fast food restaurants. American journal of preventive medicine, 48(1), 22-30.

30. Paeratakul, S., Ferdinand, D.P., Champagne, C.M., Ryan, D.H., \& Bray, G.A. (2003). Fast-food Consumption Amoung US Adults and Children: Dietary and Nutrient Intake Profile. Journal of the American Dietetic Association, 103(10), 1332-1338.

31. Rubina, A., Shoukat, S., Raza, R., Shiekh, M.M., Rashid, Q., Siddique, M.S., Panju, S., Raza, H., Chaudhry, S., \& Kadir, M. (2009). Knowledge and Practice of Healthy Lifestyle and Dietary Habits in Medical and Non-medical Students of Karachi, Pakistan. Journal of the Pakistan Medical Association, 59(9), 650-655.

32. Rydell, S.A., Harnack, L.J., Oakes, J.M., Story, M., Jeffery, R.W., \& French, S.A. (2008). Why Eat at FastFood Restaurants: Reported Reasons among Frequent Consumers. Journal of the American Diet Association, 108(12).

33. Sapic, S., Filipovic, J., \& Dlacic, J. (2019). Consumption in fast-food restaurants in Croatia and Serbia. British Food Journal, 121(8), 17151729. https://doi.org/10.1108/BFJ-04-2018-0264

34. Savige, G.S., Ball, K., Worsley, A., \& Crawford, D. (2007). Food Intake Patterns Among Australian Adolescents. Asia Pacific Journal of Clinical Nutrition, 16(4), 738-747.

35. Schröder, M.J.A., \& McEachern, M.G. (2005). Fast Foods and Ethical Consumer Value: a Focus on McDonald's and KFC. British Food Journal, 107(4), 212-224.

36. Seo, H. S., Lee, S. K., \& Nam, S. (2011). Factors influencing fast food consumption behaviors of middle-school students in Seoul: an application of theory of planned behaviors. Nutrition research and practice, 5(2), 169-178.

37. Silliman, K., Rodas-Fortier, K., \& Neyman, M. (2004). A Survey of Dietary and Exercise Habits and Perceived Barriers to Following a Healthy Lifestyle in a College Population. Californian Journal of Health Promotion, 2(2), 10-19.

38. Stewart, H., \& Yen, S.T. (2004). Changing Household Characteristics and the Away-from-home Food Market: A Censored Equation System Approach. Food Policy, 29(6), 643-658.

39. Šćepanović, Z. (2002). Upravljanje prodajom roba. Beograd: Privredni pregled i Delta M.

40. Takano, K. (2013). Communicating CSR: Case of Japanese Food Industry. International journal of Business and Management, 8(9), 111-121.

41. Tomić, M., Fočić, N., Marijanović, B., \& Topličanec, J. (2012). Habits of Croatian Students in Consumption of Fast Food. Agronomski glasnik, 74(5-6), 231-242.

42. Van den Bogaerd, M., \& Aerts, W. (2015). Does media reputation affect properties of accounts payable?. European Management Journal, 33(1), 19-29.

43. Vapa-Tankosić, J., \& Hanić, H. (2019). Uticaj percepcije potrošača o nutritivnoj vrednosti organske hrane na spremnost da se plati viša cena. Marketing, 50(3), 186-194.

44. Yahya, F., Zafar, R. \& Shafiq, S. (2013). Trend of Fast Food Consumption and its Effect on Pakistani Society. Food Science and Quality Management, 11, $1-7$.

45. https://www.kfc.rs/restorani/ (Accessed on 22 October 2020)

46. https://www.mcdonalds.rs/restorani/ (Accessed on 22 October 2020) 


\section{Apstrakt:}

\section{Stavovi i navike mladih potrošača 0 korišćenju usluga restorana brze hrane}

Dunja Demirović - Bajrami, Karolina Simat, Nikola D. Vuksanović, Marija Cimbaljević

Cilj rada je ispitivanje stavova i percepcije mladih potrošača o restoranima brze hrane u Srbiji, sa posebnim osvrtom na elemente društveno odgovornog poslovanja (brend, nutritivne vrednosti, etičke vrednosti i kvalitet hrane) i da pokaže koliko su ovi proizvodi zastupljeni u njihovoj svakodnevnoj ishrani. Podaci su prikupljani od februara do juna 2019. godine među studentima Univerziteta $u$ Beogradu i Novom Sadu, kao i među učenicima srednjih škola u Beogradu i Novom Sadu (Srbija). Ukupan uzorak činilo je 1145 mladih potrošača. Vrednosti i preferencije ciljne grupe vodećih restorana brze hrane su se promenile, kako na već razvijenom tržištu, tako i u zemljama u razvoju, kao što je Srbija. U radu su predstavljeni empirijski rezultati korišćenja usluga restorana brze hrane u Srbiji od strane mlađe populacije, kao i njihova percepcija društveno odgovornog poslovanja, sa posebnim naglaskom na restorane McDonald's i KFC.

Ključne reči: društveno odgovorno poslovanje, mladi potrošači, stavovi i percepcije, navike u ishrani, brza hrana, restorani, Srbija

\section{Kontakt:}

Dunja Demirović - Bajrami, demirovic.dunja2@gmail.com Geograsfki institut “Jovan Cvijić”, Srpska akademija nauka, Đure Jakšića 9, 11000 Beograd, Srbija

Karolina Simat, simatka@gmail.com Prirodno - matematički fakultet, Departman za geografiju, turizam i hotelijerstvo, Univerzitet u Novom Sadu,

Trg Dositeja Obradovića 3, 21000 Novi Sad, Srbija

Nikola D Vuksanović, vuksanovicnikola85@gmail.com Fakultet za menadžment, Njegoševa 1a, 21205 Sremski Karlovci, Srbija

Marija Cimbaljević, maja_0206@hotmail.com

Prirodno - Matematički fakultet, Departman za geografiju, turizam i hotelijerstvo, Univerzitet u Novom Sadu, Trg Dositeja Obradovića 3, 21000 Novi Sad, Srbija 